\title{
Connecting research and practice in TESOL: a community of practice perspective
}

Article

Accepted Version

Tavakoli, P. (2015) Connecting research and practice in TESOL: a community of practice perspective. RELC, 46 (1). pp. 37-52. ISSN 1745-526X doi:

https://doi.org/10.1177/0033688215572005 Available at https://centaur.reading.ac.uk/37981/

It is advisable to refer to the publisher's version if you intend to cite from the work. See Guidance on citing.

To link to this article DOI: http://dx.doi.org/10.1177/0033688215572005

Publisher: SAGE

All outputs in CentAUR are protected by Intellectual Property Rights law, including copyright law. Copyright and IPR is retained by the creators or other copyright holders. Terms and conditions for use of this material are defined in the End User Agreement.

www.reading.ac.uk/centaur

\section{CentAUR}


Central Archive at the University of Reading

Reading's research outputs online 


\title{
Connecting Research and Practice in TESOL: A Community of Practice Perspective
}

\begin{abstract}
In line with a growing interest in teacher research engagement in second language education, this article is an attempt to shed light on teachers' views on the relationship between teaching and practice. The data comprise semi-structured interviews with 20 teachers in England, examining their views about the divide between research and practice in their field, the reasons for the persistence of the divide between the two and their suggestions on how to bridge it. Wenger's (1998) Community of Practice (CoP) is used as a conceptual framework to analyse and interpret the data. The analysis indicates that teacher experience, learning and ownership of knowledge emerging from participation in their CoP are key players in teachers' professional practice and in the development of teacher identity. The participants construe the divide in the light of the differences they perceive between teaching and research as two different CoPs, and attribute the divide to the limited mutual engagement, absence of a joint enterprise and lack of a shared repertoire between them. Boundary encounters, institutionalised brokering and a more research-oriented teacher education provision are some of the suggestions for bringing the two communities together.
\end{abstract}

Key words: teacher research engagement, teacher education, research and practice

\section{Introduction}

Research in teaching English to speakers of other languages (TESOL) has generated a revived interest in encouraging teachers to engage in and with ${ }^{\mathrm{i}}$ research as part of their professional practice and development (Tavakoli \& Howard, 2012; Belcher, 2007; Borg, 2009, 2010; Borg \& Liu, 2013; Ellis, 2010, Erlam, 2008; Nassaji, 2012; Wright, 2010). This interest is evidenced by the increasing number of research articles, conference themes and plenary speeches dedicated to this topic to promote teacher research engagement (Borg, 2011; Ellis, 2010; Kumaravadivelu, 2011). Despite all the research interest and notwithstanding the repeated call for further research in this area (Borg; 2010; De Vries \& Pieters, 2007; Korthagen, 2007; McIntyre, 2005), there is little evidence to demonstrate that TESOL teachers engage with research as part of their day to day practice or that adequate attention is paid to examining and analysing this limited engagement. Conscious of the divide between the two and cautious of the dangers associated with it, many researchers have 
highlighted the sensitivity of the divide by calling it "a perennial problem" (Korthagen, 2007: 303), defining it "a damaging split between researchers and teachers" (Allwright, 2005:27), and describing it as "already a significant and perhaps growing divide between research and pedagogy in our field" (Belcher, 2007: 397). The gap between research and practice is commonly acknowledged across different educational disciplines from science to language education (Biesta, 2007; Korthagen, 2007; Pieters \& de Vries, 2007; Vanderlinde \& van Braak, 2010) suggesting that the problem might be more widespread than documented and "may well be an endemic feature of the field of education" (Biesta, 2007: 295).

While emerging rapidly as a global line of enquiry, there is neither sufficient empirical evidence nor adequate disciplinary effort to examine and highlight the underlying problems that help increase the divide (Biesta, 2007; Ellis, 2010; Korthagen, 2007; Nassaji, 2012). Korthagan (2007: 303) argues that given the recurrent nature of the problem and with more and more teachers, parents and politicians voicing dissatisfaction with the divide, it is necessary "to restart an in-depth analysis of the relation between educational research and educational practice". Borg (2010: 421) argues that our understanding of teacher research engagement is limited "with the levels of practical and empirical interest in this research area being minimal". Borg observes that the scope and depth of the available evidence on language teacher research clearly indicates that "teacher research remains largely a minority activity in the field of language teaching" (Borg, 2010: 391). The current paper is responding to the call for further research in this area. By providing an in-depth analysis of teachers' views and beliefs about the relationship between research and practice, the paper is an attempt to help enhance our understanding of teachers' perspectives on why they do or do not engage with research and what they suggest can be done to help improve the situation.

\section{Background Theory}

\subsection{Teaching and Research}

Before discussing the relationship between teaching and research in more detail, and against a backdrop of the disagreement among researchers and teachers about what research is, it is necessary to provide a working definition for research. Following from Dornyei (2007), for the purpose of the current study research is defined as conducting one's own databased investigation which involves collecting and analysing the data, interpreting the findings and drawing conclusions from it. The interest in encouraging TESOL teachers to engage with research can be traced back to Chastain (1976) and Stern (1982). In educational research the 
underlying assumption is that teachers who are engaged with research in their practice deliver a better quality of teaching. Williams and Coles (2003) argue that the ability to seek out, evaluate and integrate appropriate evidence from research and innovation is an important aspect of effective development in professional practice. Borg (2010: 391) reports that "research engagement is commonly recommended to language teachers as a potentially productive form of professional development and a source of improved professional practice". Teacher research is also promoted as it is known to encourage teacher autonomy, improve teaching and learning processes and empower teachers in their professional capacity (Allwright, 2005; Borg, 2010; Burns, 1999; McKay, 2009).

A brief overview of research in this area provides a list of factors contributing to the divide between teaching and practice. Pennycook (1994) interprets the divide in terms of incommensurability of discourses, and Wallace (1991) attributes it to researchers and practitioners being different people coming from different worlds. Freeman and Johnson (1998: 399) report that lack of a deep understanding and appreciation of teacher knowledge is a main issue, and argue that "research knowledge does not articulate easily and cogently into classroom practice". Non-collaborative school cultures, limited resources and limitations in teachers' skills and knowledge to do research are some of the other barriers reported in the literature (See Borg 2010 for a detailed account). Analysing the existing divide between research and practice, Ellis (2010: 2) argues that the nexus between research and practice in second language education has changed over the past years since the field "has increasingly sought to establish itself as an academic discipline in its own right”. Drawing on the literature in TESOL and Applied Linguistics, Ellis (2010) reports that there is no consensus about the relationship between research and teaching, and that the relationship continues to remain a complex and multifaceted nexus of sometimes conflicting positions on whether or not the research findings are applicable to teaching.

In a recent article, Richards (2010) calls for a better understanding of what constitute the nature of language teaching competence and performance and sets a 10-item core dimensions framework as the agenda for gaining insight into the necessary skills and expertise in language education. An important dimension that can shed light on the competenceperformance relationship, according to Richards, is 'theorizing from practice', i.e. "reflecting on our practices in order to better understand the nature of language teaching and learning and to arrive at explanations or hypotheses about them" ((Richards, 2010: 121). Richards (2010) further argues that membership of a community of practice is a core dimension that 
can provide a rich opportunity for teacher further professional engagement and development. Interestingly, Richards labelling the call 'a somewhat ambitious agenda' (p. 120) suggests that achieving this understanding might be more challenging and formidable than it is perceived.

In a study examining TESOL teachers' views on the relationship between teaching and research in England, Tavakoli and Howard (2012) reporting the findings of 60 questionnaires claimed that, regardless of the context the teachers worked in or the amount of experience they had, the majority of TESOL teachers were not engaged with research and were sceptical about the practicality and relevance of research to their professional practice. It is necessary to note that while teachers in the context of this study, i.e. England, did not mention action research as a research activity they were engaged with, action research is sometimes reported as a popular research activity in other educational contexts (Burns, 2005; Richards, 2010). The findings of Tavakoli and Howard (2012) were confirmed by Nassaji's (2012) study examining 201 TESOL teachers' views in Canada and Turkey about the relationship between teaching and research. Another interesting finding emerging from both studies is that the teachers who had some research training in their studies, e.g. those who had done a Masters' degree, had a more favourable towards the relationship between research and practice.

\subsection{Efforts to Bridge the Divide}

Stenhouse's Curriculum project (1975) has been one of the first movements to bridge the divide between educational research and practice in mainstream education in the UK. In this project, Stenhouse introduced a new approach to mainstream teaching in which an active role for teachers in developing research and curriculum in their teaching was promoted. In TESOL, such efforts are more recent. Allwright's work on promoting Exploratory Practice (2003, 2005) and Burns' innovative work advocating action research $(1999,2005)$ have been influential initiatives to raise teacher awareness and to encourage teacher research engagement. Although promoting action research, i.e. research conducted by teachers to gain a better understanding of their practice and to improve teaching and learning, has attracted attention among teachers and gained currency among researchers, the findings of recent research (e.g. Nassaji, 2012; Tavakoli \& Howard, 202) suggest that it is still not widely practiced by teachers around the world. At an organisational level, TESOL Quarterly's commitment to "publishing manuscripts that contribute to bridging theory and practice in our 
profession', and ELT Journal's mission to link 'everyday concerns of practitioners with insights gained from relevant academic disciplines' are examples of attempts to connect TESOL research and practice. Recent plenary speeches about the divide (Ellis, 2010; Kumaravadivelu, 2011) and major publications on language teacher research engagement (Borg, 2010; Ellis, 2010, 2013) are other strategies for linking the two.

The contribution of teacher education to the development of teacher research engagement is worth examining. Freeman and Johnson (1998) were among the first to suggest it was the responsibility of teacher education to link research to practice in second language education. Wright (2009) attributes a significant role to teacher education in defining and disseminating new ideas to teachers, and McKay (2009) considers introducing teachers to classroom research a challenge worth investigating. Overall, while there is a degree of awareness about the usefulness of research knowledge for and its positive impact on practice, there is insufficient evidence to indicate whether this awareness is transferred into action in teacher education and whether teacher education is effectively used as an opportunity to promote research (Borg, 2010; Kiely \& Askham, 2012; Wright, 2009, 2010).

\subsection{TESOL Teacher Education}

TESOL teacher education in the UK can be divided to two levels of initial (pre-service) and further (in-service) teacher training programs. An initial TESOL qualification, e.g. CELTA, is a certificate level qualification which has historically been a major point of entry to TESOL profession in the UK and some other countries (Kiely \& Askham, 2012). This trend is recently changing with an increasing number of employers requiring more advance qualifications, e.g. a Diploma or an MA. The certificate level teacher training programs are for graduates with little or no teaching experience (Cambridge English, 2013), and are typically intensive 4-week courses providing the skills, knowledge and hands-on teaching practice less experienced teachers need. The Diploma level teacher training programs, e.g. DELTA are designed for experienced teachers "to update their teaching knowledge and improve their practice" (Cambridge English, 2013). These usually span over two years parttime and act as in-service training and/or professional development. Both types of programs draw on the principles of reflective teaching (Schön, 1983). 
The study reported here has set out to look into TESOL teachers' views on the relationship between research and practice, to examine the potential factors they believe have contributed to the persistence of the divide, and to seek out solutions from the participants on how to bridge the divide. Of particular significance to the study is to find out if Wenger's framework for communities of practice $(\mathrm{CoP})$ can help answer the following research questions.

1. What are TESOL teachers' views on the relationship between teaching and research?

2. What factors do they hold responsible for contributing to the divide between research and practice?

3. What do they suggest can be done to help bridge the divide?

4. What role do they consider for teacher education in promoting teacher research engagement?

\subsection{Analytic Framework: Wenger's (1998) Community of Practice}

In similar areas of research, Wenger's (1998) CoP has proved an effective and constructive conceptual framework that allows for an in-depth insight to emerge from issues related to teachers' understanding, knowledge and learning in the context of their practice (Hasrati, 2005; Kiely \& Askham, 2013; Payler \& Locke, 2013; Yandell \& Turvey, 2007). Following Wenger $(1998,2000)$, this study perceives CoPs as "groups of people who share a concern or a passion for something they do and learn how to do it better as they interact regularly" (Wenger, 2006: front page). In general, CoPs are known to work in a specific Domain, have a defined Community, and exercise a specific kind of Practice. In pursuing their interest and by engaging in a series of activities such as collaborations, discussions and information sharing tasks, members of a CoP help each other, exchange experiences, develop ways of addressing and solving problems and build relationships. The interplay between social competence (shared in the $\mathrm{CoP}$ ) and personal experience (individual's own ways of knowing) is known to result in learning and the further development of a shared competence (Wenger, 2000). The shared competence emerging from participation in the social context of the CoP helps distinguish members from non-members. Wenger (1998) points out that coherence of a CoP relies on three defining elements: mutual engagement (having a common endeavour), a joint enterprise (being involved in a collective process of negotiation), and shared repertoire (developing common resources). The concept of $\mathrm{CoP}$ has been critiqued by a number of researchers as being elusive and slippery, often appropriated inconsistently in different studies (Barton \& Tusting, 2005; Rock, 2005). Other researchers have argued that 
change as an inherent property of a CoP has been neither theorised nor clearly conceptualised in Wenger's framework (Barton \& Hamilton, 2005; Barton \& Tusting, 2005). The study reported here provides an opportunity to examine whether adopting CoP as an analytic framework would allow for a better understanding of teachers' views on the relationship between TESOL teaching and research.

\section{Methodology}

\subsection{Participants}

The participants were 20 TESOL teachers teaching English in England at the time of the study. They were teaching EFL, ESOL and/or EAP courses in different organizations including university language centres, state-funded FE colleges and private language schools. To recruit the participants, a number of English language teaching institutions in England were contacted via emails and their teachers were invited to take part in the study. The 20 participants who volunteered and took part in the interviews came from a range of different educational and professional backgrounds, and had varying training and teaching experiences. The majority of the participants had taught English internationally as well, which is a typical characteristic of the UK TESOL teacher population. Given that Tavakoli and Howard (2012) did not find a significant correlation between years of experience or context of teaching and teacher research engagement, these variables were not included in the current study. While the study assumes that the participants belong to different CoPs, the focus of the study is on teacher practitioners as members of TESOL teachers' CoP. Table 1 presents some demographic information about the participants.

\section{INSERT TABLE 1 HERE}

\subsection{Interviews}

Since the two most recent studies on this topic, i.e. Tavakoli and Howard (2012) and Nassaji (2012) had drawn on questionnaire data, a semi-structured interview was considered as a methodologically more appropriate data collection tool that can make up for the limitations of previous research by providing a more open platform to the teachers to discuss their perspectives in more depth. Following from Tavakoli and Howard (2012) who found that the concept of research was open to teachers' individual interpretations, the participants were informed of the working definition of research presented earlier in this paper (see Section 2.1). The face to face interviews were conducted in a place of convenience to the 
teachers, each lasting 30 to 45 minutes. The purpose of the study was explained to the participants and informed consent was sought before the data were collected. All but one ${ }^{\mathrm{ii}}$ of the interviewees agreed that the interviews being digitally recorded.

The interview questions were guided by the previous research findings in this area. These questions can be divided to three sections. Drawing on the findings of Tavakoli and Howard (2012), the initial section of the interview aimed at investigating teachers' views on the relationship between teaching and research, the divide between the two and the main reasons for the persistence of the divide. Following from Ellis (2010) and Nassaji (2012), the second section of the interview invited the teachers to provide suggestions for bridging the gap. Questions about the role of teacher education were included in the last section of the interview as a gap in our understanding of this area has already been identified (Burns \& Richards, 2009; Wright, 2009, 2010).

\subsection{Data Analysis}

The interviews were transcribed and word processed before they were subjected to a thematic analysis (Creswell, 2007). The process involved three different stages. First, the transcripts were read and coded before a number of salient themes and patterns were identified. This then lead to grouping the themes together where possible. In the second stage, in order to examine the applicability of Wenger's CoP framework, the emerging themes were compared with the different aspects and components of Wenger's CoP discussed in Section 3 of the Introduction. These themes were then put under categories of Wenger's analytic framework to find out if they can provide a response to the research questions. In the last stage, a colleague experienced in working with Wenger's CoP framework examined the data separately. Any points for discussion or disagreement between the two coders were reconsidered until agreement was achieved.

\section{FINDINGS}

In the section below the findings of the study are grouped together to respond to Research Questions 1 to 4 in Sections 4.1 to 4.4 respectively. These findings will reflect the researcher's interpretation of teachers' views on the different aspects of teacher research 
engagement, and will highlight their suggestions on what can be done to bridge the divide between teaching and research.

\subsection{Teachers'Views on the Relationship between Research and Practice: Interdependence of Learning, Practice and Identity}

Fundamental to Wenger's concept of $\mathrm{CoP}$ is the intimate relationship between learning, practice and identity. In the field of TESOL teacher education, it is widely accepted that learning is essentially linked to the social and cultural contexts in which it occurs (Faez \& Alvero, 2012; Johnson, 2006, 2009; Miller, 2009) and that learning should be perceived as both a cognitive and sociocultural process (Lantolf, 2000; Lantolf \& Poehner, 2008; Nasir \& Cooks, 2009). From a CoP perspective, learning mainly takes place through participation in social and cultural practices and activities (Lave \& Wenger 1991; Nasir \& Cooks, 2009; Wenger, 2000), and is identified as a characteristic of practice and participation in the community of practitioners (Wenger, 1998). Members of a community learn from one another and from more experienced members of their CoP, and they change through the processes of interaction and learning. Identity in Wenger's framework is "a way of talking about how learning changes who we are" and how it creates "personal histories of becoming in the context of our communities" (1998: p. 5). The teachers in the current study frequently define their identity in terms of what they do in their every day practice and what they learn about the practice through participation and lived experiences in their CoP. They argue that learning to teach does not solely depend on research or emerge from engagement with it; it often develops through teaching, trying new techniques, exchanging experience and interacting with other practitioners.

$T 1$ : I think teaching is more a case of like, it's more a case of the hands on experience, you know. If you have a problem in class you're not going to look it up in a textbook or read about it; you'd ask someone who, someone with more experience or you just learn how to how to deal with the situation.

The teachers' message echoes Wenger's argument that "learning is not merely the acquisition of a body of knowledge, but a journey of the self' (2011). To gain knowledge about their practice, teachers rely on experience and participate in the activities of their CoP, 'old timers' helping 'new comers', enabling them to move from periphery to legitimate membership of the CoP. 
T10: Knowing where to find answers if you're a new teacher, it can be quite tricky. So,

I think if there was someone like almost like having a mentor someone who can give you advice, a lot quicker than reading research anyway.

For many of the teachers ownership of knowledge is an integral part of their professionalism and a defining aspect of their identity. They see themselves as legitimate participants who own the shared competence that results from participation in their CoP. This competence is considered as a necessary requirement of membership of their CoP and would allow for new conceptualisations to emerge. For example, the shared competence has enabled them to question the validity of the conventional definitions of research or to provide a new understanding of research that suit their practice more effectively.

T4: When you work with your students on a day to day basis you know what their needs are, that's where I would look to begin research. .... Teachers in the classroom do what works for them; a researcher can only publish what's proven through empirical evidence.

\subsection{Factors Contributing to the Divide: The Defining Elements of CoPs}

The data analysis suggests that the participants perceive teaching and research as two different CoPs and that the membership to one may not only limit but sometimes exclude a membership to the other. The analysis also implies that multi-membership in different professional CoPs has been a continuous challenge.

T5: Researchers come from theoretical perspectives; I'm a teacher coming from sort of, well, from a teaching context, from a real teaching context. ... I think um as long as the researcher hasn't been too long out of the classroom then you can rely on their research.

Wenger (1998) argues that organizing themselves around some particular area of knowledge and activity gives members of a $\mathrm{CoP}$ a sense of joint enterprise and identity. The joint enterprise is therefore their collective negotiated response to their experiences and practices, and it creates a sense of mutual accountability within the community. The inherent differences between the two CoPs should at least to some extent be attributed to the three cohering features of a CoP, i.e. mutual engagement, joint enterprise and shared repertoire. 
T13: And having a dialog between researchers and teachers: so researchers perhaps speaking with teachers about their own interests and what the teachers are interested in and developing a conversation to bridge the gap.

The pursuit of a joint enterprise, e.g. teaching English in language classroom, over time creates resources for negotiating meaning, i.e. a shared repertoire. Teachers' shared repertoire includes ways of doing things, anecdotes and stories they exchange, resources available to them and conversations in staff common rooms. A sustained engagement in their practice enables teachers to interpret and make use of this shared repertoire. The different sets of repertoire teachers and researchers rely on may be another source of divergence between the two communities.

T7: The staffroom is the best place for ideas, um I mean with all that experience why make things difficult for yourself (i.e. engage with research).

\subsection{Bridging the Gap: Bringing the Two Communities Together}

Of valuable contribution to this study is Wenger's (1998) notion of 'boundaries'. While their main function is to separate different $\mathrm{CoPs}$, boundaries come to spotlight when a required type of learning motivates members to move from one $\mathrm{CoP}$ to another. The concept of boundaries does not imply that CoPs are impermeable or that they function in isolation. Rather, connections can be made between CoPs through the use of 'boundary encounters' such as meetings and conversations, collaborative tasks, and sharing the artefacts used by them (Wenger, 1998). Given that boundary encounters allow for importing practices and perspectives from one $\mathrm{CoP}$ to another, they have a central role in bringing change to the way a community defines its own identity and practice.

T18: the main job (for the research community) then is to take research and to make it available to practitioners. It is starting the research from where the practitioners wanted.

Fundamental to success of boundary encounters is the role of brokering, "a process of introducing elements of one practice to another" (Wenger, 1998: 236). Brokers, individuals (and also institutions) who straddle different CoPs, are agents that can facilitate interaction, negotiation and other exchanges between the two CoPs. The concept of potential brokers, 
those who can connect the two communities, appeared to be a key message by the participants. While teachers teaching at universities' language centers were sometimes suggested as potential individual brokers, the main brokery role was attributed to mediatory organizations such as the British Council and the UK's National Research and Development Centre (NRDC).

T18: What NRDC did was to take research and to make it available to practitioners ... by starting the research from where the practitioners want it. Those projects and those approaches were useful and successful.

\subsection{Role of Teacher Education}

The analysis of the data provides further evidence for a socio-cultural perspective to teacher learning and confirms the significant role of learning as participation in the context of teaching (Lave \& Wenger, 1991). The teachers' views indicate that although they have found teacher education useful in providing them with the essential needs of classroom practice they concede that it is the teaching experience itself that offers them the most useful experience and a fruitful opportunity for learning.

T8: Teacher training gives you the initial tools to go and teach but I think the experience you get in your first job is much much more than the CELTA would give you.

While most teachers agreed that initial teacher training programs, e.g. CELTA, do not allow for a focus on research, the more experienced teachers argued that including research training at this stage would be pointless if not counter- productive suggesting that introducing research to teacher training would only be beneficial at a more advanced stage in teachers' careers.

T15: with CELTA (there is) very little (research) because CELTA is an initial teacher training of 4 weeks where people learn how to teach and the building blocks of that. And if you put research on top of that it's too much.

With regard to how essential research was to teachers and their professional development, the teachers' views divided. While some found it less relevant to their needs and not an 
essential requirement for becoming a professional teacher, others considered research as central to teachers' professional practice. Overall, there was an emphasis on the role of research training in encouraging teacher research engagement. Teachers who had taught at university level were often more positive about the value of research and suggested that the university environment had been supportive of this positive attitude. Promoting action research, doing a research-oriented Masters degree and including a stronger research component in teacher education were other suggestions for bridging the divide.

T16: so through a post-graduate, like a Masters degree you could sort of bridge the gap between research and practice, and that's perhaps how teachers have gone on to become researchers, I suppose. ... it'd be through teacher trainers and director of studies that research can be passed to teachers.

\section{Discussion}

One of the key points the current study highlights is the complex relationship between teachers' views on teaching and research, their learning experiences and their identity as a professional teacher. The analysis suggests that teacher identity forms and develops primarily through practicing teaching and by interacting with other teachers in their CoP. This finding is in line with Freeman and Johnson's observation that learning to teach is a long-term, complex developmental process that operates through participation in the social practices and contexts of L2 teaching (1998: 402). Unlike Varghese (2006), this finding implies that regardless of their individual expectations and personal histories, the teachers demonstrate a coherent concept of $\mathrm{CoP}$ in defining their identity in light of their teaching experience, knowledge and learning as participation. Despite acknowledging research usefulness as an underlying assumption, the teachers argue that it is learning as and through participation in the situated contexts of their CoP that gives them the ownership of knowledge and establishes them as a legitimate participant of the teaching CoP. In this respect, while it confirms Nassaji's (2012) result on teachers' lack of interest in research engagement as one of the reasons for the divide, this finding goes further to explain that teachers' reluctance may originate from teachers' reliance on the knowledge that is owned by them as legitimate participants of the CoP.

In line with the social constructivist view of teacher learning-to-teach in context (Johnson, 2006, 2009; McIntyre, 2005; Miller, 2009), the teachers in this study feel it is necessary to 
recognise their learning as situated social practice and to acknowledge and appreciate the different ways they construct and define knowledge. This is something that TESOL research should pay more attention to when studying the divide between research and practice.

Answering the question of how teacher knowledge is translated to identity and in what ways it leads to ownership of knowledge lies beyond the scope of this paper. However, the data indicates that, while teacher research engagement is limited, teachers remain committed to the principles of Reflective Teaching (Schön, 1983; Wallace, 1991) and Exploratory Practice (Allwright, 2005). Whether it is possible to follow Clark (2005) to argue that it is philosophy rather than social science that governs teaching practice is beyond the purpose of this study. What this paper can argue for is that, while research engagement seems to have a restricted impact on teachers' practice, it is imperative to find out how principles of Reflective Teaching, usually introduced to teachers during pre-service teacher education, remain embedded in teachers' professional practice in many contexts (Borg, 2010; Burton, 2009; Kiely \& Askham, 2012; Miller, 2003; Wright, 2010).

To associate practice and community, the three dimensions of relation in the community, i.e. mutual engagement, shared repertoire and joint enterprise should be strengthened. One way to investigate the divide is to find out why these dimensions in each $\mathrm{CoP}$ are diverting from those of the other. William and Coles' (2007) findings from a survey of 312 teachers in the UK that report informal discussions with colleagues, professional magazines and newspapers, and in-service teacher education are the three most common sources of teachers' new knowledge. This is an example of the limited shared repertoire between teachers and researchers. The concept of "barriers to engagement with and in research" is not new in the literature, with scholars such as Borg (2010) and Ellis (2010) listing key obstacles that prohibit teachers from conducting research. Although the presence of these barriers cannot be denied and their impact on deepening the divide should not be undermined, the underlying problem for the limited teacher research engagement reported in the literature is more complex than the simple concept of barriers. In line with the findings of Flores (2001), the current study suggests that the impact of pre-service and initial teacher education preparing teachers for research engagement is limited. It is also known that the role of teacher education in preparing teachers for research engagement has been minimally investigated (Faez \& Alvero, 2012; Kiely \& Askham, 2012; Miller, 2009; Wright, 2010). 


\section{Concluding Remarks}

Employing Wenger's (1998) CoP framework in this study has offered an insight into the complex relationship between knowledge, learning experiences and identity, and has opened up a novel way of interpreting the divide in the light of the differences between the two CoPs. However, using this framework has undermined the role of social forces at work in the creation of CoPs, e.g. the social force that imposes on researchers a research agenda distant from teachers' practical needs (Rock, 2005). Given the dynamic nature of a CoP, it is impossible to consider or evaluate it without taking into account how the world around a CoP influences it. In the current study, however, to achieve the research aims CoPs are considered in isolation. It is necessary to note that this is a small-scale study drawing on a small set of data in England. Although many of its findings may endorse issues, dilemmas and problems previously reported in various contexts, the impact of local pedagogies (Kumaravadivelu, 2011) should not be underestimated.

There are a number of important conclusions this paper would find necessary to draw on. First, the findings of this study strongly suggest that teachers' knowledge and experience, developing through practice in their CoP, should be acknowledged and valued more intensely by the research community. Research that is aimed for TESOL teachers should be informed by this knowledge and experience, and should be designed to address their needs and requirements. Second, there is a strong need for researchers and teachers to build joint communities and to engage in mutual activities that can bring together a research and a practical focus. In order to indicate their membership to these different but inter-connected CoPs and to help bridge the divide, teachers, researchers and mediatory communities, e.g. the British Council should take a more active role in promoting collaborative research, running joint projects and holding shared academic and educational events. Richards (2010) refers to a number of successful projects of this kind delivered in the Asian contexts. The question to ask is if such projects can be used as a model to follow in other similar contexts. The final concluding remark is to highlight the important role of teacher education programmes in enhancing a research environment and in encouraging a research approach to teaching. Research evidence (e.g. Erlam, 2008; Wright, 2010) suggests that providing a more userfriendly approach to research combined with a supportive research environment on teacher training programmes would not only prepare teachers for a better engagement with research, but they would build confidence and lead to teacher empowerment. 


\section{References}

Allwright, D. (2003). Exploratory practice: Rethinking practitioner research in language teaching. Language Teaching Research, 7(2), 113-141. doi:

Allwright, D. (2005). From teaching points to learning opportunities. TESOL Quarterly, 39(1), 9-31.

Barton, D. \& Tusting, K. (2005). Beyond communities of practice: Language, power and social context. Cambridge: Cambridge University Press.

Barton, D. \& Hamilton, M. (2005). Literacy, reification and the dynamics of social interaction. In D. Barton and K. Tusting (eds.), Beyond communities of practice: Language, power and social context (pp. 14-35). Cambridge: Cambridge University Press.

Belcher, D. (2007). A Bridge Too Far? TESOL Quarterly, 41(2), 396-399.

Biesta, G. (2007). Bridging the gap between educational research and educational practice: The need for critical distance. Educational Research and Evaluation, 13(3), 295-301.

Borg, S. (2009). English language teachers' conceptions of research. Applied Linguistics, $30(3), 358-388$.

Borg, S. (2010). Language teacher research engagement. Language Teaching, 43(4), 391-429. Borg, S., \& Liu, Y. (2013). Chinese College English Teachers' Research Engagement. TESOL Quarterly, 47(2), 270-299.

Britten, D. (1985). Teacher training in ELT. Language Teaching, 18(2), 220-238.

Burns, A. (1999). Collaborative action research for English language teachers. Cambridge: Cambridge University Press.

Burns, A. (2005). Action research: An evolving paradigm? Language Teaching, 38(2), 57-74.

Burns, A., \& Richards, J. C. (2009). The Cambridge guide to second language teacher education. Cambridge: Cambridge University Press.

Burton, J. (2009). Reflective Practice. In A. Burns \& J. C. Richard (Eds.), Cambridge guide to second language teacher education (pp. 298-308). Cambridge: Cambridge University Press.

Cambridge ESOL. (2013). Retrieved from www.cambridgesol.org

Chastain, K. (1976). Developing second language skills: Theory to practice. Michigan: Harcourt Brace. 
Clark, C. (2005). The structure of educational research. British Educational Research Journal. 31(2), 289-308

Creswell, J. W. (2007). Qualitative enquiry and research design. London: Sage Publications.

De Vries, B., \& Pieters, J. (2007). Knowledge sharing at conferences. Educational Research and Evaluation,, 13(3), 237-247.

Dornyei, Z. (2007). Research methods in applied linguistics. Oxford: Oxford University Press.

Ellis, R. (2010). Second language acquisition, teacher education and language pedagogy. Language Teaching, 43(2), 182-201.

Ellis, R. (2013, July). Making the link between pedagogic-discourse and research-based discourse. Plenary talk at the Ninth Annual Meeting of British Association of Applied Linguists (BAAL) Language Learning and Teaching SIG. Twickenham: UK

Erlam, R. (2008). What do you researchers know about language teaching? Bridging the gap between research and language pedagogy. Innovations in Language Learning and Teaching, 2(3), 253-267.

Faez, F., \& Valeo, A. (2012). TESOL Teacher Education: Novice Teachers' Perceptions of Their Preparedness and Efficacy in the Classroom. TESOL Quarterly, 46(3), 450-471.

Farrell, T. (2006). The first year of language teaching: Imposing order. System, 34(2), 211222.

Farrell, T. (2009). The novice teacher experience. In A. Burns \& J. C. Richard (Eds.), The Cambridge guide to second language teacher education (pp. 190-198). Cambridge: Cambridge University Press.

Flores, M. (2001). Person and context in becoming a new teacher. Journal of Education for Teaching, 27(2), 135-148.

Freeman, D. (2009). The scope of second language teacher education. In A. Burns \& J. C. Richard (Eds.), The Cambridge guide to second language teacher education (pp. 1119). Cambrdige: Cambridge University Press.

Freeman, D., \& Johnson, K. (1998). Reconceptualizing the knowledge-base of language teacher education. TESOL Quarterly, 32(3), 397-417.

Han, Z. (2007). Pedagogical implications: Genuine or pretentious. TESOL Quarterly, 41(2), 387-393. 
Hasrati, M. (2005). Legitimate peripheral participation and supervising Ph. D. students. Studies in Higher Education, 30(5), 557-570.

Johnson, K. (2006). The sociocultural turn and its challenges for second language teacher education. TESOL Quarterly, 40(2), 235-257.

Johnson, K. (2009). Second language teacher education: A socio-cultural perspective. New York: Routledge.

Kiely, R., \& Askham, J. (2012). Furnished Imagination: The Impact of Preservice Teacher Training on Early Career Work in TESOL. TESOL Quarterly, 46(3), 496-518.

Korthagen, F. (2007). The Gap Between Research and Practice Revisited. Educational Research and Evaluation, 13(3), 301-310.

Kumaravadivelu, B. (2011, October). Connecting global cultures and local identities in the English language classroom. Paper presented at the $19^{\text {th }}$ TESOL Korea, Seoul, South Korea.

Lantolf, J. (2000). Sociocultural theory and second language learning. Oxford: Oxford University Press.

Lantolf, J., \& Poehner, M. (2008). Sociocultural theory and the teaching of second languages. London: Equinox.

Lave, J., \& Wenger, E. (1991). Situated learning legitimate peripheral participation. Cambridge: Cambridge University Press.

McIntyre, D. (2005). Bridging the gap between research and practice. Cambridge Journal of Education, 35(3), 357-382.

McKay, S. (2009). Second language classroom research. In A. Burns \& J. C. Richard (Eds.), The Cambridge guide to second language teacher education (pp. 281-288). Cambridge: Cambridge University Press.

Miller, J. (2003). Researching teacher-consultancy via exploratory practice. Language Teaching Research, 7(2), 201-219.

Miller, J. (2009). Teacher identity. In A. Burns \& J. C. Richard (Eds.), Cambridge guide to second language teacher education (pp. 172-181). Cambridge: Cambridge University Press.

Nasir, N. S., \& Cooks, J. (2009). Becoming a hurdler: How learning settings afford identities. Anthropology and Education Quarterly, 40(1), 41-61.

Nassaji, H. (2012). The relationship between SLA research and language pedagogy: Teachers' perspective. Language Teaching Research. 16(3), 337-365. 
Payler, J., \& Locke, R. (2013). Disrupting communities of practice? How "reluctant" practitioners view Early Years Workforce Reform in England. European Early Childhood Education Research Journal, 21(1), 125-137.

Pennycook, A. (1994). Incommensurable discourses. Applied Linguistics, 15(2), 115-138.

Reber, A. (1993). Implicit Learning and Tacit Knowledge: An essay on the cognitive unconscious. Oxford: Oxford University Press.

Richards, J. C. (2010). Competence and performance in language teaching. RELC. 41(2): 101-122.

Roberts, J. (2006). Limits to communities of practice. Journal of Management Studies, 43(3), 623-639.

Rock, F. (2005). "I've picked up some from a colleague": language, sharing and communities of practice in an institutional setting. In D. Barton and K. Tusting (eds.). Beyond communities of practice: Language, power and social context (pp. 77-104). Cambridge: Cambridge University Press.

Schön, D. (1983). The Reflective Practitioner: How professionals think in action. London: Temple Smith.

Shkedi, A. (1998). Teachers' attitudes towards research: A challenge for qualitative researchers. Qualitative Studies in Education, 11(4), 559-577.

Stenhouse, L. (1975). An introduction to curriculum research and development. London: Heinemann.

Stern, H. H. (1982). Fundamental concepts of language teaching. Oxford: Oxford University Press.

Tavakoli, P. \& Howard, M. J. (2012). TESOL teachers' views on the relationship between research and practice. European Journal of Teacher Education. 35(2): 229-243.

Tennant, M. (1997). Psychology of adult learning. London: Routledge.

Vanderlinde, R., \& van Braak, J. (2010). The gap between educational research and practice: views of teachers, school leaders, intermediaries and researchers. British Educational Research Journal, 36(2), 299-316.

Varghese, M. M. (2006). Bilingual Teachers-in-the-making in Urban town. Journal of Multilingual and Multicultural Development, 27(3), 211-224.

Wallace, M. (1991). Training foreign language teachers: A reflective approach. Cambridge: Cambridge University Press. 
Wenger, E. (1998). Communities of practice: Learning, meaning and identity. Cambridge: Cambridge University Press.

Wenger, E. (2000). Communities of practice and social learning systems. Organization, 7(2), 225-246.

Wenger, E. (2006). Communities of Practice: A brief Introduction. Retrieved July 15, 2013, from http://www.wenger.com/theory

Wenger, E. (2011). Learning in and across landscapes of practice. Retrieved May 15, 2013, from http://www.lancs.ac.uk/celt/celtweb/ewenger

Williams, D., \& Coles, L. (2007). Teachers' approaches to finding and using research evidence: an information literacy perspective. Educational Research, 49(2), 185-206.

Wright, T. (2009). "Trainer development": Professional development for language teacher educators. In A. Burns \& J. C. Richard (Eds.), The Cambridge guide to second language teacher education (pp. 102-112). Cambridge: Cambridge University Press.

Wright, T. (2010). Second language teacher education: Review of recent research on practice. Language Teaching, 43(3), 259-296.

Table 1: Participants' profile

Participants Teaching context Years of experience Teaching qualification

$\mathrm{T} 1$

$\mathrm{T} 2$

$\mathrm{T} 3$

$\mathrm{T} 4$

T5

T6

$\mathrm{T} 7$

$\mathrm{T} 8$

T9

\section{EAP}

ESOL

ESOL \& EAP

ESOL \& EFL

EFL

EFL

EFL

EAP \& ESOL

EFL
Certificate \& Diploma

Certificate \& MA

Certificate \& Diploma

Certificate, Diploma \& MA

less than a year

Certificate

Certificate

Certificate

Certificate \& Diploma

Certificate 
'Borg (2009) distinguishes between teachers' engagement in research and with research. For the purpose of this study as such distinction has not been found necessary, the term engagement with research is used consistently to represent both types of engagement.

ii In the case of the only interviewee who didn't agree for her voice to be recorded, detailed notes were taken. 